\title{
Benign Hemangioendothelioma
}

National Cancer Institute

\section{Source}

National Cancer Institute. Benign Hemangioendothelioma. NCI Thesaurus. Code C66779.

A benign vascular proliferation characterized by the presence of prominent endothelial cells and the formation of vascular channels. 